\title{
Front Matter: Volume 9526
}

, "Front Matter: Volume 9526," Proc. SPIE 9526, Modeling Aspects in Optical Metrology V, 952601 (21 June 2015); doi: 10.1117/12.2197968

SPIE. Event: SPIE Optical Metrology, 2015, Munich, Germany 


\title{
PROCEEDINGS OF SPIE
}

\section{Modeling Aspects in Optical Metrology V}

\author{
Bernd Bodermann \\ Karsten Frenner \\ Richard M. Silver \\ Editors
}

23-25 June 2015

Munich, Germany

Sponsored by

SPIE

Cooperating Organisations

European Optical Society

German Scientific Laser Society (Wissenschaftliche Gesellschaft

Lasertechnik e.V.)

Published by

SPIE 
The papers included in this volume were part of the technical conference cited on the cover and title page. Papers were selected and subject to review by the editors and conference program committee. Some conference presentations may not be available for publication. The papers published in these proceedings reflect the work and thoughts of the authors and are published herein as submitted. The publisher is not responsible for the validity of the information or for any outcomes resulting from reliance thereon.

Please use the following format to cite material from this book:

Author(s), "Title of Paper," in Modeling Aspects in Optical Metrology V, edited by Bernd Bodermann, Karsten Frenner, Richard M. Silver, Proceedings of SPIE Vol. 9526 (SPIE, Bellingham, WA, 2015) Article CID Number.

ISSN: 0277-786X

ISBN: 9781628416862

Published by

SPIE

P.O. Box 10, Bellingham, Washington 98227-0010 USA

Telephone +1 3606763290 (Pacific Time) · Fax +1 3606471445

SPIE.org

Copyright (@ 2015, Society of Photo-Optical Instrumentation Engineers.

Copying of material in this book for internal or personal use, or for the internal or personal use of specific clients, beyond the fair use provisions granted by the U.S. Copyright Law is authorized by SPIE subject to payment of copying fees. The Transactional Reporting Service base fee for this volume is $\$ 18.00$ per article (or portion thereof), which should be paid directly to the Copyright Clearance Center (CCC), 222 Rosewood Drive, Danvers, MA 01923. Payment may also be made electronically through CCC Online at copyright.com. Other copying for republication, resale, advertising or promotion, or any form of systematic or multiple reproduction of any material in this book is prohibited except with permission in writing from the publisher. The CCC fee code is 0277-786X/15/\$18.00.

Printed in the United States of America.

Publication of record for individual papers is online in the SPIE Digital Library.

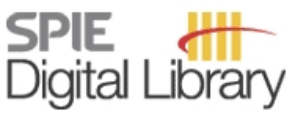

SPIEDigitalLibrary.org

Paper Numbering: Proceedings of SPIE follow an e-First publication model, with papers published first online and then in print. Papers are published as they are submitted and meet publication criteria. A unique citation identifier (CID) number is assigned to each article at the time of the first publication. Utilization of CIDs allows articles to be fully citable as soon as they are published online, and connects the same identifier to all online, print, and electronic versions of the publication. SPIE uses a six-digit CID article numbering system in which:

- The first four digits correspond to the SPIE volume number.

- The last two digits indicate publication order within the volume using a Base 36 numbering

system employing both numerals and letters. These two-number sets start with 00, 01, 02, 03, 04, $05,06,07,08,09,0 A, 0 B \ldots$ OZ, followed by 10-1Z, 20-2Z, etc.

The CID Number appears on each page of the manuscript. The complete citation is used on the first page, and an abbreviated version on subsequent pages. 


\title{
Contents
}

\author{
vii Authors \\ ix Conference Committee
}

\section{SESSION 1 SCATTEROMETRY I}

952605 Enlarging applicability domain of the $C$ method with piecewise linear parameterization: gratings of deep and smooth profiles (Invited Paper) [9526-1]

952606 Specialized scatterometry methods for two types of gratings with distinct groove profiles [9526-2]

952607 Spatial mode projection for side-wall angle measurements [9526-3]

\section{SESSION 2 INTERFEROMETRY AND PHASE I}

952608 Phase error analysis and compensation in fringe projection profilometry (Invited Paper) [9526-4]

952609 Signal simulation method for homodyne multiple target interferometers using short coherence length laser sources [9526-8]

9526 OA Metrological characterization of a large aperture Fizeau for $\mathrm{x}$-ray mirrors measurement [9526-7]

9526 OC A way for measuring the relationship between DM surface and wave-front aberrations in a beam rotate $-90^{\circ}$ laser system [9526-9]

\section{SESSION $3 \quad$ RADIOMETRY AND PHOTOMETRY}

9526 OD Optical detectors based on thermoelastic effect in crystalline quartz (Invited Paper) [9526-10]

9526 OF Numerical modeling and uncertainty analysis of light emitting diodes for photometric measurements [9526-11]

\section{SESSION 4 OPTICAL SYSTEMS}

9526 OG Horizontal geometrical reaction time model for two-beam nacelle LiDARs [9526-14]

$9526 \mathrm{OH}$ Investigation vignetting beams in optoelectronic autocollimation angle measurement system [9526-15] 
9526 Ol Transferring the Rb+hyperfine-structure stability to a Fabry-Perot resonator used as a frequency standard for astronomical spectrographs [9526-19]

9526 OK Wide-aperture laser beam measurement using transmission diffuser: errors modeling [9526-18]

$9526 \mathrm{OL}$ Application of the ARMA model in distributed fiber vibration sensing system [9526-16]

\section{SESSION 5 STOCHASTIC SCATTERING AND NANOPARTICLES}

$95260 \mathrm{M}$ Simulating the coherent light propagation in a random scattering materials using the perturbation expansion (Invited Paper) [9526-20]

9526 ON The optical properties of tropospheric soot aggregates determined with the DDA (Discrete Dipole Approximation) method [9526-21]

952600 Detection of fast flying nanoparticles by light scattering over a large volume [9526-23]

9526 OP Nonspherical nanoparticles characterization by partially depolarized dynamic light scattering [9526-22]

\section{SESSION 6 OPTICAL MATERIAL PARAMETERS AND THIN FILMS}

$95260 Q \quad$ Nondestructive measurement of two-dimensional refractive index profiles by deflectometry (Invited Paper) [9526-24]

9526 OR Problems in thin film thickness measurement resolved: improvements of the fast Fourier transform analysis and consideration of the numerical aperture of microscope headers and collimators [9526-25]

\section{SESSION 7 SCATTEROMETRY II}

9526 OS Methods for optical modeling and cross-checking in ellipsometry and scatterometry (Invited Paper) [9526-27]

9526 OU The statistical inverse problem of scatterometry: Bayesian inference and the effect of different priors [9526-29]

$9526 \mathrm{OV}$ The effect of systematic errors on the hybridization of optical critical dimension measurements [9526-30]

\section{SESSION 8 MICROSCOPY AND IMAGING}

$9526 \mathrm{OW}$ Simulation of light in-coupling through an aperture probe to investigate light propagation in a thin layer for opto-electronic application [9526-33] 
9526 OX Effect of wavefront aberrations on a focused plenoptic imaging system: a wave optics simulation approach [9526-34]

9526 OY Total variation iterative constraint algorithm for limited-angle tomographic reconstruction of non-piecewise-constant structures [9526-35]

$95260 Z$ A cascaded plasmonic superlens for near field imaging with magnification [9526-36]

\section{SESSION 9 INTERFEROMETRY AND PHASE II}

952610 Calibration of the amplification coefficient in interference microscopy by means of a wavelength standard (Invited Paper) [9526-37]

952611 In-line digital holography with double knife edge [9526-38]

952612 Fourier analysis of quadratic phase interferograms [9526-39]

952613 Phase retrieval based on diffraction element array with single far field [9526-40]

952614 Dynamic stitching interferometric testing for large optical plane [9526-41]

\section{SESSION 10 MUELLER POLARIMETRY}

952616 Snapshot polarimeter based on the conical refraction phenomenon [9526-46]

952617 Measurement errors induced by axis tilt of biplates in dual-rotating compensator Mueller matrix ellipsometers [9526-43]

952619 Correction of depolarization effect in Mueller matrix ellipsometry with polar decomposition method [9526-45]

9526 IA Parallel aligned liquid crystal on silicon display based optical set-up for the generation of polarization spatial distributions [9526-47]

\section{POSTER SESSION}

9526 1B A novel autocollimating method for measuring the focal distances [9526-48]

9526 1C Modelling of microcracks image treated with fluorescent dye [9526-49]

9526 ID High-angle light scattering to determine the optical fiber core [9526-51]

$9526 \mathrm{IE}$ Research of the use of autoreflection scheme to measure the error of the optical elements in space telescope's relative position [9526-52]

9526 IF Modeling and analysis of the solar concentrator in photovoltaic systems [9526-53] 
9526 IG In situ estimate of duty cycle of surface-relief holographic gratings during development by measuring TM/TE diffraction efficiency ratio [9526-54]

$95261 \mathrm{H}$ Investigation of a mathematical model of the system of electro-optical sensors for monitoring nonlinear surfaces [9526-55]

952611 Using quaternions to control assembly and adjustment mirror-prism optical systems [9526-56]

9526 IL Maximum power point search method for photovoltaic panels which uses a light sensor in the conditions of real shading and temperature [9526-59]

$95261 \mathrm{M}$ The study of the structural stability of the spiral laser beams propagation through inhomogeneous phase medium [9526-60]

9526 iN Simulation and analysis of lightweight space mirror design [9526-62]

952610 Propagation invariant laser beams for optical metrology applications [9526-63]

$95261 Q$ Determination of refractive index by Moiré deflectometry [9526-26] 


\section{Authors}

Numbers in the index correspond to the last two digits of the six-digit citation identifier (CID) article numbering system used in Proceedings of SPIE. The first four digits reflect the volume number. Base 36 numbering is employed for the last two digits and indicates the order of articles within the volume. Numbers start with 00, 01, 02, 03, 04, 05, 06, 07, 08, 09, OA, OB...0Z, followed by 10-1Z, 20-2Z, etc.

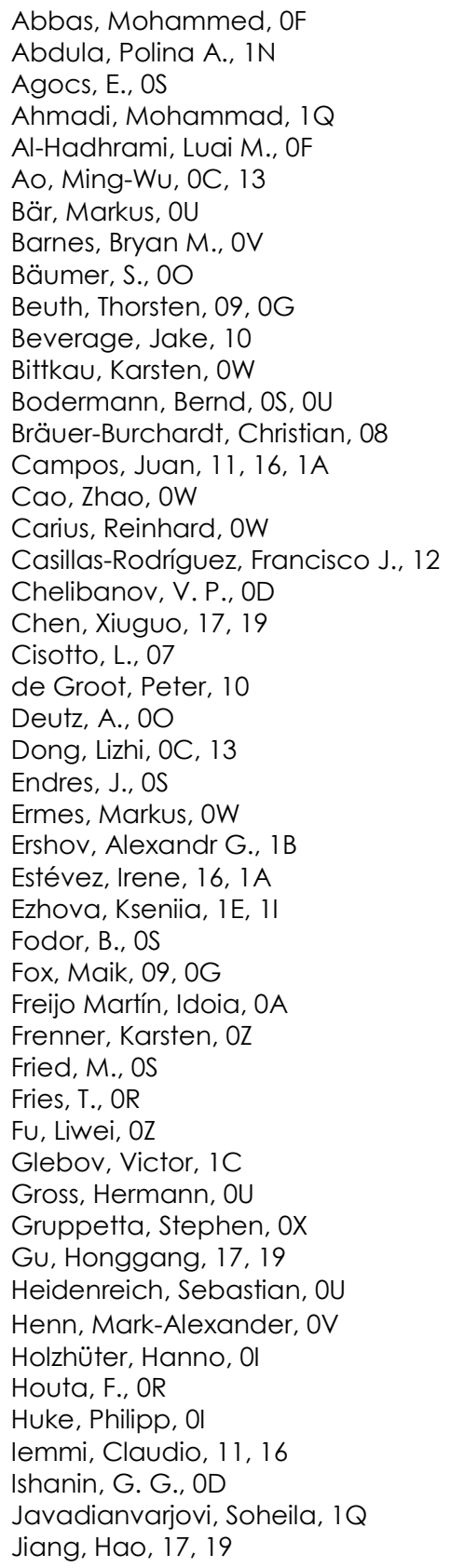

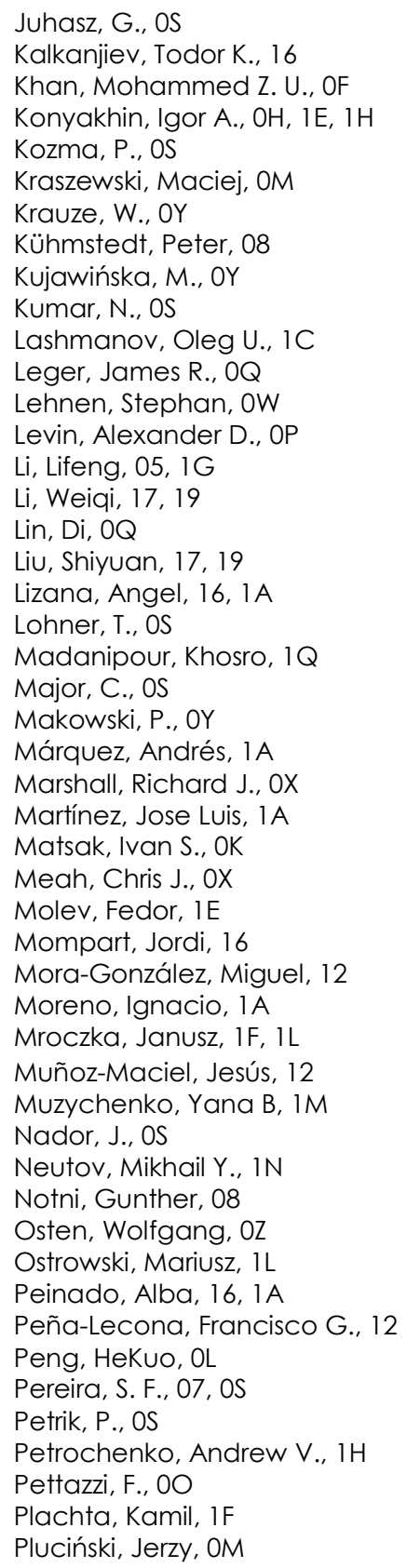


Qi, Te, 14

Quinten, M., OR

Ramírez, Claudio, 11, 1A

Reiners, Ansgar, 01

Sakhariyanova, Aiganym M., $\mathrm{OH}$

Schau, Philipp, OZ

Shen, Biyao, $1 \mathrm{G}$

Shmytkova, Ekaterina A., OP

Silver, Richard M., OV

Skorupski, Krzysztof, ON

Smekhov, Andrey, $\mathrm{OH}$

Soskind, M., 10

Soskind, Y. G., 10

Stork, Wilhelm, 09, 0G

Strq̨owski, Marcin R., OM

Streck, Andreas, 09

Styles, lain B., OX

Świrniak, Grzegorz, 1D

Tan, Yi, OC

Tolstoba, Nadezhda D., iN

Trojanowski, Michal, OM

Turola, Massimo, OX

Turpin, Alex, 16

Urbach, H. P., 07, OS

van der Donck, J., 00

Vannoni, Maurizio, OA

Wang, Shuai, OC, 13

Wu, Hongyan, OL

Wu, Xin, 14

Wurm, Matthias, OU

$\mathrm{XU}$, Bing, 13

$X \cup$, Haiyan, $\mathrm{OL}$

$\mathrm{Xu}, \mathrm{Xihong}, 05$

Yang, Lin, 06

Yang, Ping, 0C, 13

Yu, Yingjie, 14

Zeng, Lijiang, $1 \mathrm{G}$

Zhang, Chuanwei, 17, 19

Zhang, Linna, 14

Zhang, Nien Fan, OV

Zheng, Xuejie, $1 \mathrm{~A}$

Zhou, Hui, OV

Zhu, Yan, 07

Zinchik, Alexander A., 1M

Zverev, Victor, 11 


\title{
Conference Committee
}

\author{
Symposium Chairs
}

Wolfgang Osten, Institut für Technische Optik (Germany)

Gunther Notni, Fraunhofer-Institut für Angewandte Optik und

Feinmechanik (Germany)

Andrew John Moore, Heriot-Watt University (United Kingdom)

Conference Chair

Bernd Bodermann, Physikalisch-Technische Bundesanstalt (Germany)

Conference Co-chairs

Karsten Frenner, Institut für Technische Optik (Germany)

Richard M. Silver, National Institute of Standards and Technology (United States)

Conference Programme Committee

Markus Bär, Physikalisch-Technische Bundesanstalt (Germany)

Jörg Bischoff, Osires Optical Engineering (Germany)

Harald Bosse, Physikalisch-Technische Bundesanstalt (Germany)

Sven Burger, Konrad-Zuse-Zentrum für Informationstechnik (Germany)

Peter Evanschitzky, Fraunhofer-Institut für Integrierte Systeme und

Bavelementetechnologie IISB (Germany)

Christian Hafner, ETH Zürich (Switzerland)

Wolfgang Holzapfel, DR. JOHANNES HEIDENHAIN GmbH (Germany)

Bernd H. Kleemann, Carl Zeiss AG (Germany)

Wolfgang Osten, Institut für Technische Optik (Germany)

Andreas Rathsfeld, Weierstrass-Institut für Angewandte Analysis und Stochastik (Germany)

Thomas Scherübl, Carl Zeiss SMS GmbH (Germany)

Patrick Schiavone, Aselta Nanographics (France)

Irwan D. Setija, ASML Netherlands B.V. (Netherlands)

Michael Totzeck, Carl Zeiss AG (Germany)

Jari Turunen, University of Eastern Finland (Finland)

Frank Wyrowski, Friedrich-Schiller-Universität Jena (Germany)

Session Chairs

1 Scatterometry I

Sven Burger, JCMwave GmbH (Germany) 
2 Interferometry and Phase I

Bernd Bodermann, Physikalisch-Technische Bundesanstalt (Germany)

Christof Pruss, Institut für Technische Optik (Germany)

3 Radiometry and Photometry

Liwei Fu, Universität Stuttgart (Germany)

4 Optical Systems

Wolfgang Holzapfel, DR. JOHANNES HEIDENHAIN GmbH (Germany)

5 Stochastic Scattering and Nanoparticles

Egbert Buhr, Physikalisch-Technische Bundesanstalt (Germany)

6 Optical Material Parameters and Thin Films

Michael Schulz, Physikalisch-Technische Bundesanstalt (Germany)

7 Scatterometry II

Bernd Bodermann, Physikalisch-Technische Bundesanstalt (Germany)

8 Microscopy and Imaging

Karsten Frenner, Institut für Technische Optik (Germany)

9 Interferometry and Phase II

Wolfgang Osten, Institut für Technische Optik (Germany)

10 Mueller Polarimetry

Peter Petrik, Research Institute for Technical Physics and Materials Science (Hungary) 